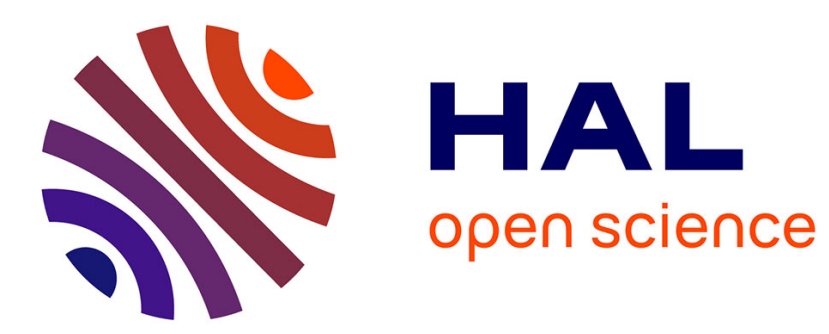

\title{
Social economy as social science and practice: historical perspectives on France
}

Danièle Demoustier, Damien Rousselière

\section{To cite this version:}

Danièle Demoustier, Damien Rousselière. Social economy as social science and practice: historical perspectives on France. Eleventh World Congress of Social Economics "Social economics : a paradigm for a global society", Albertville, 8-11 Juin 2004, 2004, pp.41. halshs-00102532

\section{HAL Id: halshs-00102532 \\ https://shs.hal.science/halshs-00102532}

Submitted on 2 Oct 2006

HAL is a multi-disciplinary open access archive for the deposit and dissemination of scientific research documents, whether they are published or not. The documents may come from teaching and research institutions in France or abroad, or from public or private research centers.
L'archive ouverte pluridisciplinaire HAL, est destinée au dépôt et à la diffusion de documents scientifiques de niveau recherche, publiés ou non, émanant des établissements d'enseignement et de recherche français ou étrangers, des laboratoires publics ou privés. 


\title{
Eleventh World Congress of Social Economics \\ Social Economics: A Paradigm for a Global Society, Albertville, France \\ June 8-11, 2004
}

\section{Social Economy as Social Science and Practice: Historical Perspectives on France ${ }^{1}$}

\author{
Danièle DEMOUSTIER \\ ESEAC ${ }^{*}$, Institut d'Etudes Politiques de Grenoble \\ Damien ROUSSELIERE \\ LEPII $^{* *}$, CNRS-Grenoble II \\ Session : Social Economics and Economic Sociology
}

\begin{abstract}
Résumé
Dans cet article, nous nous intéressons aux significations du terme polysémique d' «économie sociale », apparu à la fois comme concept dans le cadre de la création d'une science sociale en lien avec les traditions libérale, chrétienne ou socialiste des économistes et pour désigner un ensemble de pratiques et/ou d'institutions, avec l'implantation du capitalisme en France. Une mise en perspective historique montre les rapports ambivalents entre ces deux grandes acceptions. En conclusion, nous en tirons quelques pistes de réflexion pour un renouvellement du programme de recherche sur l'économie sociale.
\end{abstract}

Mots clés :

économie sociale ; histoire de la pensée ; coopératives ; science sociale

\section{Abstract}

This article aims to investigate the multiple meanings of "économie sociale" ("social economy"), a term which first appeared in France at the founding moment of modern capitalism, both as a concept in the framework for the creation of a social science in close relation with the tradition of classical, Christian and socialist economists, and also to establish an ensemble of social practices and institutions. A historical perspective shows the close yet ambivalent relationship between these two principal connotations. Stemming from this, the conclusion presents some new research orientations towards social economy as a social science and social practice.

\section{Classification JEL :}

A12 Relation of Economics to Other Disciplines - B30 History of Thought - L31 Nonprofit Institutions - N00 Economic History - General - P13 Cooperative Enterprises

\footnotetext{
${ }^{1}$ We are grateful to Zakir Paul (Université Paris III)) for the precise and rigorous translation of this text, as well as Geneviève Rousselière (Université Paris I) for her editorial assistance.

* Equipe de Socio-Economie Associative et Coopérative

** Laboratoire d'Economie de la Production et de l'Intégration Internationale
} 


\section{Social Economy as Social Science and Practice: \\ Historical Perspectives on France}

\section{Introduction: The definition of Social economy, a recurrent question}

A confluence of current research is vying to elucidate the criteria of adhesion to social economy. In fact, researchers are being called upon to clarify the stakes of and the debates on the identity of organizations that can — or could potentially—classify themselves as belonging to the realm of "social economy," while ongoing social, economic, political and cultural changes have exercised wide influence transforming the surrounding context. On the one hand, they effect old organizations that recognize themselves in this term, both due to their status (cooperative, mutualist and associative) and to their administrative functioning (the production of goods and services, utilities). They seem to live off the very contradictions that distance certain organizations among them from the solidarity built up in the 70 s and the $80 \mathrm{~s}$, which leads others, in turn, to redefine their projects (Vienney [1994]). On the other hand, they provoke the emergence of new organizations that sometimes identify themselves as belonging to the sphere of "civil and solidarity-based economy" [économie solidaire] not always defining their economic function or their solidarity. Thus the actors themselves, the authorities and public opinion on the whole, demand more legibility, in order to recognize the particularity of forms of economic production that assert themselves increasingly in a service (relational, creative, financial, etc.) economy ${ }^{2}$.

In this article, it seems important to put into perspective the current debates by returning to the history of the constitution of social economy as a social science and as a field of analysis, regrouping under this term certain social practices. From the emergence of the term Social Economy (and of its practice) in the $19^{\text {th }}$ century, it became necessary to explore the particularity of organizations united under this term. Debates arose on the nature as well as the role of these organizations, in relation to Liberal, Christian, or socialist traditions of economists who claim to belong to a social science called social economy as well. In the beginning of the $20^{\text {th }}$ century, the workers associations having given way to cooperation, similar debates opposed different conceptions of cooperation until the moment of cooperative unity that Georges Fauquet conceptualized, prefiguring the 1947 legislation on cooperation.

\footnotetext{
${ }^{2}$ As is clearly indicated by the evolution of employment in the French service workers coops $(+62 \%)$ and in the associations $(+15 \%)$ over the last five years. (Demoustier, Rousselière [2003]).
} 
Once again, since the 1970s, different terminologies have been opposed, covering, here as well, political issues around the particularity of these organizations, and thus of their relations to public policy and profit-making economy, as well as the role that these organizations are brought to play in the current transformations.

Like "économie", which in French means both economics and economy, the term "social economy" [économie sociale] has multiple meanings. It appeared, simultaneously, both as a concept in the context of the creation of a social science and to designate a group of practices and institutions, with the onset of capitalism in France, the culmination of which is the 1981 entry into French law of a definition of a new type of company.

- As a concept, social economy was understood in the $19^{\text {th }}$ century, either as the enhancement of political economy (the production of means of existence beyond material production) by liberals like Charles Dunoyer [1830] in the heritage of an author like John Stuart Mill [1848], or as a critique of and the substitute for political economy (by Christians and socialists like Auguste Ott [1851]), or as comprising political economy (Proudhon's social science - as analyzed by Giovanna Procacci [1993]), or else, finally as a complement to pure economics, identifying with the overall rise of public economics (Walras [1896], Gide [1905]).

In the 20th century, the concept disappeared, replaced by an economy of solidarity [économie de solidarité], inspired by Solidarism (Gide [1924]), followed by cooperative economy [économie coopérative] theorized in the Revue des Etudes Coopératives - founded in 1921 by Charles Gide and Bernard Lavergne - then by Georges Fauquet [1935]), or even new economy [économie nouvelle] (which appeared furtively in 1936 in the context of a theory of distributive socialism by Georges Valois), due to the rise of economics and of its specializations (notably public economy)...until its re-apparition in the 1970s and its interaction with other terms such as third-sector, alternative economy, solidarity-based economy, the non-profit sector...in the 1980 s and the 90 s.

- As an ensemble of practices and institutions, social economy has progressively freed itself, in the course of the $19^{\text {th }}$ century, from home economics, then from patronage in order to recover principally Associative Economics [Charles Gide's l'économie

\footnotetext{
${ }^{3}$ Claude Vienney notes: "whereas we do not confound life and biology, nor society and sociology, the same word 'économie' is used to designate both the described realities themselves and the method used to furnish a specific representation of them" (Vienney [1994], p.72).
} 
associationiste] (larger than "democracy-based economy" today) followed by the rise of public intervention. Its rediscovery in the $20^{\text {th }}$ century marks, on the other hand, the rising autonomy of private collective organizations, in relation to their integration in public interventions (cooperatives/ public markets, associations/ public policies, mutual societies / Social Security), all the while in opposition to, as particular forms of non-capitalist or a-capitalist companies, a redundancy and a selectivity imposed by competition and finance.

As we are setting out a history of ideas, put into relation with economic and social history, we may take as a general hypothesis the ambivalent relations between science and social practice, for the larger part of social reconfigurations are always accompanied, on the conceptual level in social sciences, by vast re-interpretative undertakings, of hybridization and conceptual innovation that set out to capture the ongoing processes (Rémond [1987], pp. 769-770). On the other hand, as André Gueslin ([1998], pp. 381-407) shows, the cooperative movement and social economy have always sought to appropriate (going beyond the actual historic relation) myths and foundational theories ${ }^{4}$, for itself, defining in this sense a particular doctrine of a period (Draperi [2000]). Our reflection will thus play out in multiple steps:

- First of all, it is necessary to return to the debate about the $19^{\text {th }}$ century and the question of the constitution of social economy in its relation to classical political economy (as its potential continuation, critique or an alternative);

- With the constitution of economic science by Walras, Gide and Fauquet, we note that social economy as a concept and as a practice separates into Walrasian social economy on the one hand (defined henceforth in a restrictive manner as the Welfare Economics) and cooperative economy, on the other hand, which should be understood as an analytic method specific to organizations.

- From the 1970s onwards, the return of the term "social economy", taken in a narrower sense than in 1900, became the object of intense debates concerning its conceptualization, while new structures with new objectives were coming up: integration in work, housing, healthcare; fair trade; local services, social enterprise often regrouped under the term solidarity-based economy [l'économie solidaire].

\footnotetext{
${ }^{4}$ This ambiguity can also be found in the double-activity of theorists who also were involved in practical action: P. Buchez who helped to create the Christian association of gold jewelers; L. Blanc initiated social workshops; P.-J Proudhon created a People's Bank; K. Marx was a founding member of the International Workingmen's Association; C. Gide was the president of a federation of cooperatives; L. Walras was the president of a bank for the development of cooperatives, etc.
} 
- In conclusion, from the lessons drawn from this historical approach, we put forth some potential points of departure for a renewal of research in social economy.

\section{Social economy and classical political economy}

In the early $19^{\text {th }}$ century, the term 'social economy' ${ }^{5}$ was used in extremely diverse ways, which Henri Desroche has analyzed around three ideological traditions-liberal, Christian and socialist (Desroche [1983])—which nonetheless had common objectives: "social economy means, no more no less, another way to do political economy" (Gueslin [1998], p.1). It actually advocates an enlargement, even an opposition to industrial economy, which does not take the living conditions of the working class into account. This term imposes itself across the World Fairs that consecrate and popularize it, enclosing the collective means of improving the condition of the working class, in revealing the transformations; in putting the emphasis first on patronage (1867), then on labor associations (1889) and finally on the collection of "institutions of social progress" (1900).

\section{Social economy as an enhancement of political economy}

In his history of social economy, André Gueslin reminds us that "certain economists do not hesitate to use the concept of social economy, very early on, in an epoch when it differs very slightly from the concept of political economy" (Gueslin [1998], p.115). Thus, in 1830, Charles Dunoyer publishes a Treatise on Social Economy in which he claims to complete the definition of productive means of wealth by "the funds of personal faculties", refuting the restrictive analysis of the production of wealth by classical economists: "M. Say has shares with Adam Smith, the fault of not counting amongst these [wealth producing] means all the part of social funds that are employed to satisfy needs in general: we deem unproductive all the capital employed in the upkeep of men, like all the arts that act durably on them" (Dunoyer [1830], Tome 2, p. 551). Comprising all the analysis of the means that lead to wealth beyond the sole production of exchangeable values, social economy necessitates the study of, "not only how the social body becomes rich, but the laws according to which it comes to execute freely all its functions, by what means men come to use their forces with

\footnotetext{
${ }^{5}$ Our approach implies that we are not dealing with Charles Fourier nor with Robert Owen (even if nonetheless we are going to address Marx's relation to Proudhon) although their importance is doubtless in the genesis of social practices (cf. the familistère of Guise inspired by the phalanstère of Fourier; the experiences of Stock Exchange or communities advocated by Owen) (Gueslin [1996]). The authors we are taking up were inspired by them in many aspects of their theories. For a general overview of $19^{\text {th }}$ century thinkers linked with social economy, you can refer to Gueslin [1998] and Desroche [1981, 1991].
} 
greater ease, extent and plenitude" (Dunoyer [1830], Tome I, p. 405). This idea of the construction of social economy as an extension of political economy by a broadening of its field of analysis to all that is useful, responding to needs and desires, taking away from it all naturalist determination and all moral content draws mainly on the utilitarian approach of John Stuart Mill [1889]. The latter had already put forth the importance of "productive consumption" (health, education) which, in satisfying the most important needs of men, contributes at the same time to collective enrichment (Mill [1848]) ${ }^{6}$.

For these liberals, the "immaterial functions" must reinforce liberty and morality. In fact, for Dunoyer they integrate the sources of health, well-being and the healthy life, stimulants for intelligence and training, as well as the learning of mores and "good civil habits", that is to say the moral norms and the liberty of expression and education necessary for all proper economic functioning. On this level, these ideas come close to those of Malthus, since "the laboring classes must raise themselves up through work, foresight, and morality." He is thus at one with the liberals who favor associations between workers and bosses, where "free and voluntary association" at that (according to Frédéric Bastiat [1864], p. 550) join up with the tradition started by John Stuart Mill on social value and the economy of association. The latter is perceived as being "the closest imaginable combination to social justice and the most characteristic of the organization in the interest of all." The association will replace the salaried state in stages: "temporary association in certain cases, workers with the entrepreneur; in other cases, and finally in all cases, the workers associations amongst them" (Mill [1848], cited by Vienney [1960], p. 104). Cooperation has an economic interest because it leads to the suppression of useless intermediaries and middlemen; it also plays a part in social progress through the moralization and control of the working classes ${ }^{7}$.

In relation to these liberal traditions, one of the ways initiated by social economy as social practice is thus constituted around patronage by the establishment of institutions of mutual benefit and forecasting (controlled by notable citizens) and the participation of workers in benefits, whose living conditions can be bettered by the creation of a social environment

\footnotetext{
${ }^{6}$ It is striking to note that, since the $19^{\text {th }}$ century, the English title "Principles of Political Economy, with some of their Applications to Social Philosophy" has systematically been translated into French by "Principes d'économie politique avec quelques-unes de leurs applications à l'économie sociale (social economy)". This underlines the intellectual filiation.

${ }^{7}$ Auguste Casimir-Périer's enthusiasm [1864, p. 28] is expressed in these words: "What great moral and material advantages! Only with his resolution to free himself from his past debts, if ever he has any, the associate gets the
} 
marked by paternalism (worker's housing, collective gardens, childcare...). When it comes to the practices of "the laying out of traditional employer relations, praised by Le Play, it is in the domain of credit cooperation that the liberals would bring a real contribution to the constitution of a sector of social economy" with the import of the Italian model of People's Banks (Banques Populaires) (Gueslin [1998] p. 138).

\section{Critique of political economy and the right to work by association}

A little later in the social-Christian tradition of the followers of Saint-Simon, a reformist current develops an approach in social economy, thought of as a critique of political economy. The associationnistes, such as Philippe Buchez (1796-1865) and his follower, the Alsatian jurist Auguste Ott (1814-1903) as well as the republican journalist Louis Blanc (1811-1882), will defend the idea of workers association as the guarantee of the right to work, in the struggle against pauperism, based on a denunciation of the harmful effects of competition and of its theoretical basis that lie in classical political economy (Smith, Say, Bastiat) (Demoustier, [2003]).

Setting itself against the "English principle" of the separation of sciences, which consists of "political economy as having to constitute itself as the science of wealth in order to place itself outside the entirety of human knowledge," (Ott [1851], p. 5) Auguste Ott denounces the assimilation of physical laws to those of the "moral world." Physical forces are predetermined, whereas man is free; their effects are independent of each other, whereas the actions of men living in communities are interdependent. "In short, so that only the gravitation of natural forces could create order in political economy, it would be prerequisite that man would not be a free being. Secondly, either he wouldn't be obliged to live in society, or else forecasting and common action would not be the sine qua non of social life" (Ott, [1851], p. 184). For instance, the empirical observation of the harmful effects of competition, factor of crises, of disorder in production and consumption, leads the authors to refute the theory of Say. "The law of Say is nothing but pure chance" affirms Auguste Ott ([1851], p. 5). It follows that the auto-regulation of the market must therefore be replaced by social prevision. Louis Blanc denounces equally the systematic search for the lowering of prices: "a good deal, that's the catch word which sums up all the benefits of unlimited competition, according to the economists of the school of Smith and Say. But why think of the results of a good deal 
exclusively in relation to the momentary benefit that the consumer draws from it? A good deal [a cheap price] profits those who consume only in throwing the seed of the most ruinous anarchy amongst those who produce" (Blanc [1847], p. 77). The objective of these theorists is to contribute to pointing out economic reality in a broader way, by taking into account not only production and the repartition of social wealth as classical political economy does, but also the problems posed by consumption (and the qualitative and quantitative proportion of products to needs) as: "society does not produce what is indispensable and necessary for all, and yet it cannot place all its products" (Ott, [1851], p. 84).

Social economy is a science, which like all science must not only differentiate between its object and its goal, but the latter must also be subordinate to a more general principle of justice ("the organization of work in conformity to moral law) (Ott, [1851], p. 17) ${ }^{8}$. Thus August Ott declares: "We have preferred the term Social economy, already proposed by several economists, to that of Political economy as it is commonly used; firstly because the first term has a reforming value that the second notion lacks and thus, in consequence, it better indicates our tendency and our goal, next because it is etymologically more precise since society has gone beyond the limits of antique cities" (Ott, [1851], p. IX). Social economy, thus conceived, leaves great room for association, seen as "the key word of the problem posed to modern civilization" (Ott, [1851], p. 132). "As it is practiced today, the association considered as a means to liberate the laboring classes and to give them the ownership of the instruments of work [is an idea that belongs] to M. Buchez" (Ott, [1851], p. 133). Buchez had in fact promised "the association of work and not that of capital" by "the constitution of a common social capital which would be inalienable and indivisible" (the origin of unshared reserves which remains one of the common criteria for the associative, mutualist or cooperative status), as "the means for improving the condition of city workers" (Buchez, [1831]). Erasing the distinction between the different social classes, notably those of the capitalist and the worker, "only [the association] can erase the inferiority and the dependency of the working classes. Also, it alone can stop these abuses of competition that lead to the lowering of prices of products, but only at the expense of the worker's life" (Ott, [1851], p.191).

\footnotetext{
While living better, he makes savings and the attraction of savings, once begun, is well-known."

${ }^{8}$ Thus social economy is: "the science that aims to organize work towards the most perfect preservation of society and the individual and of the achievement of liberty, equality and fraternity" (Ott [1851], p. 20). According to Ott, this goal unifies the social sciences (direct human activity towards the good), but they due to
} 
This association belongs to the larger general program of social reform through the constitution of ad hoc institutions. Thus Buchez, like Ott, expressed the need for a special bank destined to give credit to associations. Endowed by the state, it could call for public savings: "being above all an institution of public utility rather than a work of speculation, it would call out to the capital of all individuals wanting to contribute to social reform" (Buchez, [1866]). Blanc widens this role of the state, seen as a "Bank for the poor" (Blanc, [1847], p. 14), which, qua financer, would have to intervene as a regulator, as well, in order to put technical progress at the service of society.

It was actually the Buchezian theses rather than those of Louis Blanc which prevailed at the heart of the interim government of 1848, one of its first measures being a proclamation of the right to association ${ }^{9}$. On the other hand, despite the presence of Louis Blanc at the presidency of the Luxembourg Commission (as a substitute for a Labor Minister called for by the workers), the model of national workshops for the unemployed took priority over social workshops for workers of strategic industries. After their closing in June 1848, the National Assembly supported the workers associations by authorizing them a credit of three million francs. This credit would back the opening of 300 production associations, a certain number of which gathered bosses and workers from the workshops.

But at the same time-1848-50 - the state restricted them from federating, before entirely abrogating the right of association in 1851. And thus so many projects carried out by the Seine workers were destined to fail successively; these projects sought not only to reduce competition between associations but also to support new creations, and, beyond that, to escape the constraints of competition between producers:

- A central committee of the worker's delegation to the Luxembourg commission to increase solidarity and reduce the rivalry between associations;

- A union chamber of workers associations to bind the associations to one another by credit (for the acquisition of tools and raw materials) and by the exchange of credit;

- The union of the labor associations (put forth by two women Flora Tristan and Jeanne Deroin) to elaborate a common credit fund [caisse de crédit et de solidarité] exchange

their object (organization of the polis and power for politics, the order of work for economics, the administration of state interests for administrative science etc.) 
bonds refundable in association products, in proportion to consumption and production needs, based on the refusal of "legal tender [as] a source of monopolization."

Their activity would last a short while; suspicion and police repression would put an end to the objectives of overcoming competition amongst associations, of reconciling independence and fraternity in inter-associative relations, and that of harmonizing equality and authority within the association itself (Desroche [1981, 1991]).

Thus at the turning point of the assertion of French Capitalism, the analyses of these authors express a great suspicion towards competition, which is accused of being the cause of all the ills suffered by the working class. Nonetheless they hold an extreme confidence in the democratic state and the workers morale, in money and in credit, in forecasting and in the capacity of labor associations to appropriate and spread technical progress (Demoustier, [2003]). The alternative model is based on the conjunction of democracy (the state representing the general interest and not the strongest private interests), the association (cooperation rather than competition) and training (to raise the workers morale and consciousness). Subsequently, this gave rise to fecund exchanges between worker's practices and propositions and forms of theory, from whence there emerged different experiments (association of gold jewelers (1834-1873), trial unions of associations...) rendered obsolete by political orchestration and repression.

\section{From the emancipation through cooperation and mutual benefit to reform through social economy}

In the continuation of this critique of political economy, the movement of "scientific" socialism (a procedure of the foundation of an economic science that identifies itself with Marx as well as Proudhon ${ }^{10}$ ) will abandon the term of social economy in order to examine the concrete structures of cooperation, coming from the English co-operation used in France from 1860 onwards to differentiate the associative enterprise from political associations ${ }^{11}$.

\footnotetext{
${ }^{9}$ The revolution also marks the moment when a policy of financing companies through the Comptoir National d'Escompte, a pact between the State, the Communes and private subscriptions was taken (Stoskopf [2002]).

${ }^{10}$ Proudhon notes that "modern socialists all claim their allegiance to a unified and indivisible science, but they are not able to agree about the content, the limits or the methodology of this science" (Proudhon [1846], Tome 1, p. 41).

${ }^{11}$ For instance, the journal Association, disappeared in 1860, reappeared two years later under a new title Cooperation.
} 
A debate opposes Marx and Proudhon on the power of emancipation of the labor association; for Marx, only political association (The International Workingmen's Association) feeding the political struggle can come to this end. The "cooperation" is in keeping with political economy of work but various experiments cannot suffice and risk turning away the labor movement from a more general goal. So, nowadays, even as we are witnessing a rereading of Marx as a thinker of labor managed economy and a promoter of worker's cooperatives (Texier [2002]), it is necessary to pay attention to Marx's ambiguous references to "the political economy of the working class" ${ }^{\prime 2}$. In the augural address to the International Workers Association, Marx salutes the cooperative movement as a "great victory of the political economy of labor over the political economy of property", but puts forth two principal series of criticisms which limit the extent of this victory. On the one hand cooperation lacks an intrinsic dynamic likely to energize it own expansion. Limited to sporadic and occasional tries, the cooperative movement is "powerless to transform capitalist society on its own" or to "arrest the growth in geometrical progression of monopoly" (Marx [1963], p.1469). Moreover, cooperative action does not constitute an efficient means for "freeing the masses, nor even for perceptibly lightening the burden of their misery". As a result, it cannot be the most important domain of worker's action. On the other hand, the cooperatives of production that are formed in capitalist society cannot attain or even claim to be the most definitive form of associated work: "in their actual organization, we are confronted with all the defaults of the existing system" (Marx [1959], p. 105). They represent at most "a turning point between the capitalist mode of production and the associative production" of post-capitalist society. Nonetheless, these two critical reservations - one coming from an examination of the potential means of the general abolition of salary, the other dealing with the very nature of cooperative work at the heart of actually existing society-do not strip cooperation of its importance: "without making up the main or exclusive means of workers' action, the idea of cooperation is intimately linked, in Marx's point of view, with the end of such action.: the establishment of 'a republican system of association of free and equal producers"” (Lowitt, [1962], p. 84).

\footnotetext{
${ }^{12}$ They can be found in book III of the Capital, the Civil War in France, the Critique of the Gotha Program and the Inaugural address to the International Workingmen's Association.
} 
Proudhon goes against this analysis in talking as his basis the constitution of a social science ${ }^{13}$ as "the accord of reason and social practice," the end of which is the safeguard of the human personality (Neurisse, [1983], p. 31). Coming up in a perspective of social justice through the progressive building up of compromise, realized between different "economic contradictions" (Proudhon [1846]), this social science is based on "a profoundly original conception of "justice," which is simultaneously a real process of balancing social and physical forces, as well as an "ideal" process, catalyzing the antagonistic forces of the human psyche. Through its social, moral and personal practice, it becomes-coupled with workers action and teaching — the ideo-realistic process of a permanent revolution" (Bancal, [1987], p. 268).

The instigator behind Marx's theory of exploitation, Proudhon denounces "the right of escheat" [droit d'aubaine] allowed by capitalist property, which allows the owner the capacity to extricate the value that collective labor will create (Proudhon [1840]). By eliminating useless intermediaries, the "mutual society" is alone in representing both the interests of consumers and producers. A common federation would permit the arbitration of any divergence of interests, as would be the case with the constitution of an industrialagricultural union in an industrial-agricultural federation and the unions of consumers that together form "a production-consumption union". It is the latter that will survey the cooperative organization of services (commerce, housing, insurance, credit) and the non-state management of economic society. The management would in turn be backed up by the application of mutual systems in credit and exchange with the creation of a "people's bank" or an "exchange bank," which while doing away with interest based loans, would promote the "solution of the social problem" (Proudhon [1953], p.42).

These oppositions cross the French worker's movement, which in its meetings from 1876 to 1879, distanced itself progressively from Proudhon's theses, in favor of Marxist theories spread by Jules Guesde, challenging labor cooperation, while cautiously promoting consumer cooperation. In 1879, critiques were even more virulent, like those of Isidore Finance who denounced not only the cooperation of production-as "a bottomless pit where all the vigorous forces of the proletariat come to dissolve and to disappear"-but also cooperation in general: "cooperation is nothing but a name: it is largest divisor of the working class"

\footnotetext{
${ }^{13}$ This social science then includes "social economy" as defined by the previous authors. It is "today rather an aspiration towards the future rather than knowledge of reality ; one must acknowledge that the elements of this study are all found in political economy" (Proudhon [1846], p. 54).
} 
(Finance, [1879], p. 329). This was happening at the very moment that the Republicans, following the liberals of the Second Empire, were using cooperation as "a bulwark against Socialism"14. At the end of the century, Jean Jaurès tried to reconcile political, union and cooperative action, for "the democratic state is the supreme cooperation towards which the other cooperatives stretch as if as towards their limit" (Jaurès [1903], p.37). But, despite the experiments of the stock-exchange of socialist cooperatives and The Albi Workers' Glassworks (workers glassworks, "belonging to the entire working class" (Gide [1923], p. 242) at the heart of which the workers are represented by the CGT [Confédération Générale du Travail, The General Confederation of Labor, one of France's main trade union] and not directly associated with the management of the firm) the rupture with the union movement is already complete since 1879 .

In this context, it is moreover the reformative role of social economy and labor associations that dominates the turn of the century. Ever since the mid $19^{\text {th }}$ century, the World Fairs introduced sections on social economy, the definition of which evolved from home economics, "the science of a happy life,"15 to patronage, then to worker's association and finally to public regulation. "The idea of making Social Economy a part of the world fairs, goes back to Frédéric le Play, who, for the first time, applied it to the exposition of 1855" (Desroche [1983], p. 71). For the 1867 world fair, under the influence of Le Play and the Société d'économie sociale, a tenth group was obliged to "carefully research and clarify all that contributes to the betterment of the physical and moral conditions of the classes devoted to manual labor," that is to say, "free, secular [lä̈que] or religious societies, captains of industry or rural development, or individuals," promoting the initiatives coming from bosses and neglecting the associative sector. In 1889, the presentation of social economy was organized by the followers of Le Play, such as Léon Say and Emile Cheysson, but the report was written by a Republican, Alfred Picard, who was more in favor of workers associations (even if Léon Say also considered them as a means to fight against "state socialism" (Desroche [1991], p. 145)). "It was clearly necessary to bring to the public attention all the institutions created by the bosses, the workers, the state, by the cities, as well as by the private sector, in the aim of mutual benefits, savings and physical and moral well being". Distinct from the "social

\footnotetext{
${ }^{14}$ As Auguste Casimir-Périer [1864, p.8] puts it: "the free, voluntary association, based on mutuality and solidarity, acting with collective forces but granting its compounding individual forces their value and reward is not only far from resembling communism in any aspect, but is precisely its contrary. It is its firmest condemnation; it is the safest and the most generous remedy against mistakes and dangers of socialism."
} 
efforts" that attempted to increase the well-being of workers through economic forecasting, there were diverse movements that based their efforts on the reduction of the cost of living and the cost of production in cottage industries; or else focused their concern on the moral and preventive action in a domestic household, as well as on the practice of hygiene; patron institutions; and finally "State Socialism", in relation to individual initiatives (Desroche [1991], pp.139-146).

\section{Social Economy and the constitution of Economics}

The turn of the century is an important moment according to Claude Vienney [2000]. It is from this point onwards that the definition of academic social economy will be established, especially following Léon Walras, as the analysis of fields of activity and categories of actors, the study of which necessitates an interdisciplinary combination of economics, law and sociology, "due to their institutional particularities, references to social justice or to the irrelevance of explanations based solely on the market" (Vienney [2000], p. 38). Social economy thus includes the labor economy, health, education etc ${ }^{16}$. This meaning imposed itself in the academic world at the same time as the constitution of a specific analysis of the cooperative sector, as a separate branch of research.

\section{Social economy between morality and science: The Walras/Gide debate}

Already in 1896, Léon Walras defined l'économie sociale, in his "Studies in Social Economics", as the voluntary distribution of wealth, based on the criteria of the "just," thus differentiating itself from the natural production through "Pure Economics", which like all science seeks to discover the "true" (Dockès [1996]). But it is primarily the public economy that designates such rising state intervention for the redistribution of wealth. The "popular cooperative associations" participating in the production of wealth figure in "Applied Economics" as a means to attain the ideal of "Pure economics", with the particularity of allowing those who brought in work, consumers, or small investors, to become capitalists as well through the development of an individual or collective savings plan (Demoustier [2001 b]). Three types of working-class associations are listed:

\footnotetext{
${ }^{15}$ The 1855 World Fair includes a home economics gallery based on the realizations of the Industrial Company of Mulhouse.

${ }^{16}$ This meaning was passed on in France through associations of scholars like the AES (Association d'Economie Sociale) or can be found in published works such as Batifoulier [1995].
} 
- Working class consumer associations for whom social capital is formed through the progressive collection, by the partners, of salary surpluses produced over the salaries consumed;

- The production associations in small and mid-sized industries. Theoretically the association allows the status of a worker-entrepreneur;

- The credit associations that also have the capacity to transform the worker into a capitalist, taking a part of his salary from him, as a contribution, then transformed into forced savings. Instead of doing away with capitalism, the cooperative movement facilitates access to it.

The workers movement must reunite members that, in so much as collective entrepreneurs have the same right to decide the future of the unity of production, in keeping with the democratic principle of "one member, one vote". Moreover, the principle of competition inexorably remains the rule (no specific support from the state). Finally, the size of the company must be controlled, for the principle of cooperation can only apply to the context of small and mid-sized firms.

For Léon Walras, the association movement does not at all respond to the problem of social justice. Taking up the legacy of John Stuart Mill, who denied all autonomous conceptions of cooperation, Walras declares that this must be considered according to the "principles of political economy" as a form of free and voluntary association from individual initiatives. In encouraging service providers on the market and the entry of workers to the "owners' class," working class associations do only "what political economy says" (Walras [1865], p. 11). That is to say, the advent of social and economic progress by the considerable rise of wealth brought about by the access to credit, through "the enormity of dividends compared to the low contributions." On the terrain of production and exchange, they combine economic progress with social and moral progress, since they "fulfill their great economic role which is not to get rid of capital, but to make everyone a capitalist, as well as their no less important moral role which is to introduce democracy to the mechanism of production and to clear its way to access business, the veritable school of active politics" (Walras [1898], p. 261). One must thus see "in cooperative association the last word, the supreme effort and the definitive success of individual initiative" (Walras [1896], p. 21). 
Charles Gide differentiates himself from Léon Walras, an author with whom he lies in close correspondence (Desroche [1993]), for he proposes a definition of the cooperative as the framework for the reconciliation of divergent interests in the name of a superior principle of justice (the just price theory ${ }^{17}$ ) as consumers that create cooperatives defend, "their interests vigorously, that moreover get confounded, and herein lies their strength, with the more general interests of the business" (Gide [1926], Tome II, p.479). The cooperative thus allows the transformation of conflicts between men into conflicts within each man, thus laying the basis of a solidarity that Gide does not observe but desires (Vienney [1960], p. 131) ${ }^{18}$. If he deems the cooperative domain more likely to facilitate the peaceful resolution of conflicts, it's because he thinks that each individual, in this domain, will play multiple roles: "these antagonisms (between buyers and sellers, debtors and creditors, etc.) that as long as they were taken from the outside and on the economic market had a necessarily combative character and were thus demoralizing, from the day they transform into interior conflicts, take on a moral value on the contrary. They give rise to reflection rather than hate. It is the best form of character building education to have to argue the pros and cons in one's conscience" (Gide [1924], p. 36).

In 1900, the report of the sixth division on "social economy" of the World fair was written by Charles Gide ${ }^{19}$. Theoretically, Gide turns to the definition of Walras that differentiates "Pure economics" (natural laws of production of wealth), "Applied Economics" and "Social Economics" (a voluntary approach to the redistribution of wealth). But after this normative definition, he develops a very pragmatic description that corresponds more to "the study of all the efforts made to better the condition of the people". After having suggested, in the 1905 edition, that three rankings of institutions of social economy were possible: according to their

\footnotetext{
17 "That is to say a price high enough so that it could cover all costs of production and even answer to all economic necessities that are summed up in the formula 'law of supply and demand', but a price cleared of usurious surcharges due only the coalition of producers and the ignorance of consumers" (Gide [1926], Vol. 2, p. 485). André Gueslin notes the proximity of Gide's approach with the theory of justice developed by Gabriel Tarde (Gueslin [1996], p. 151).

${ }^{18}$ This is a reference to the two stages of political economy developed by Charles Gide. On the one hand the pure political economics is a "study [of] spontaneous relationships that are formed between men living in groups (...). It does not suggest judging them from a either moral or a practical point of view, but only to explain what is"). On the other hand, social economics "studies rather voluntary relationships that men form with each other taking the form of associations, legislation or any institutions - so as to improve their living conditions. It proposes to seek out and assess the best means to achieve this goal. While doing this, it is rather part of the spirit of moral sciences for it searches what ought to be and to the spirit of arts for it searches what is to be done" (Gide [1926], p. 3).

${ }^{19}$ Gide took part in a cycle of conferences in 1890 organized by the Swiss Society of Social Economy that distinguished "four schools of social economy": the Christian school of Le Play, the collectivist school, the New School of C. Gide and the liberal School (Gide [1890]).
} 
characteristics, their origins and their goals, he keeps only the last two. Thus the institutions of social economy are divided between "all the forms of free association that leans to the emancipation of the working class by its own means ${ }^{20} \ldots$ all the forms of state intervention...all the forms of proprietary institutions" that participate in four major objectives: raising salaries, the rise in comfort and well-being, security for tomorrow and independence. The term of association used by Charles Gide covers "infinitely varied forms that are far from being known altogether" (L'émancipation, cited in Draperi [1998]). Which is why, Gide, in the different editions of his report, progressively abandons the term of social economy, giving up on an expression "the indeterminacy of which could well lead to misunderstanding". It has been republished many times under the title "Institutions of Social Progress" (Penin [1990]).

Of these institutions, the public institution, through its economic and social interventions, which took the form of social economy under Fordism (Demoustier [2001 a]), well described by the French Regulation School (Boyer, Saillard [2002]), will then undergo a growing recognition as one of the determining actors of social progress.

\section{From social economy to cooperative economy: On Georges Fauquet's contribution}

The crisis of the 1930s rehabilitated the cooperation which benefited, from this point on, from access to public markets ${ }^{21}$ and took hold strongly in the domain of consumption and agriculture; but at the same time the cooperation is shot full of conflicts notably concerning the evaluation of cooperation developed by Charles Gide, as well its role in economic and political transformations ${ }^{22}$.

Holding the chair in cooperation at the ILO (International Labor Organization), Georges Fauquet is pragmatic rather than doctrinaire. He develops the same process as Charles Gide's approach in so far as he wants to integrate "man as a whole," into his system; the subtitle of his book is expressive as it is an "Essay on man's place in cooperative institutions and their place in the economy". This proposition is a reflection on the necessary unity of the economic and social aspects of the cooperative experience: "the capitalist and market based economy

\footnotetext{
${ }^{20} \mathrm{He}$ counts more than 45000 associations in activity.

${ }^{21}$ Numerous bankrupt companies are then transformed into workers coops; one of the greatest workers coops is still in activity, the ACOME (European leader of the cable market) was created at that time.

${ }^{22}$ As the first Employer's organization to sign a collective convention with the CGT, the Fédération Nationale des Coopératives de Consommation actively take part in the Rassemblement du Front Populaire.
} 
(...) has gradually detached the economic from the social and thus, given birth to hard realities that served as a model for the abstractions of economists. Conversely, the cooperative institutions, by restituting to the associates the function that the salesman had taken away, reintegrate the economic into the social" (Fauquet [1935], p. 44).

Moreover, this author sets up a distinction between cooperatives and working class associations in emphasizing economic activity rather than political action: by their origins, their background, their social classes where they are born and developed, the cooperative institutions are related to all kinds of workers associations. To the benefit of the same categories, albeit through their own methods, they translate the same effort of defense, of recovery and emancipation. What sets them apart from forms of action and working class associations, is that they pursue their goal using an organized economic activity, through the means of a company" (Fauquet [1948]). Despite the divisions that oppose the different forms of cooperatives according to their sectors of activity and above all the nature of their membership ${ }^{23}$, Georges Fauquet advocates the unity of the cooperation in showing, from notions of service and of double quality, that on the one hand the cooperative is a business at the service of its members and not an firm out to profit its shareholders, and that on the other hand, a member of the association is both a member of the cooperative association and a user of the cooperative enterprise. Herein lies the source of the rules of indivisible resources, of equality between the members (the basis of democratic functioning) and of the proportionality in the individual redistribution of surplus (a prorate discount on activity).

Setting himself apart from the coopératisme of the Rochdale pioneers, from the Gide of the cooperative period (the three steps towards making the economy entirely cooperative [coopératisation] (Gide [1910])), Georges Fauquet proposes an argument in terms of sectors (a notion used "for the facility of a simplified schema" (Fauquet [1935], p. 35)). The cooperative sector shares economic activity with the private sector (small, agricultural or artisanal businesses), the profit-making sector and the public sector. Though it is coextensive to the private sector, the "cooperative sector" maintains with these two sectors relations of a different kind: "with the profit-making sector, there are relations of competition and struggle which does not however exclude commercial relations at the heart of national economies or

\footnotetext{
${ }^{23}$ Thus the division between, on the one hand, workers cooperatives and consumers cooperatives for the emancipation of the working class and, on the other hand, cooperatives of consumers and farmers' cooperatives for supply.
} 
on the international market; with the public sector: complex and variable relations following the degree of development of cooperative institutions and the political and economic orientation of the state" (Fauquet [1935], p. 36).

In this context, the cooperative sector can only lay claim to development in the initial and final phases of the economy, to protect the independence of small groups (agricultural, artisanal and homemade productions) and not in the central phases of transformation of goods, where capitalism flourishes. In order to do this, Fauquet calls for state support that he does not judge well adapted to the direct management of economic activities, but which, alone can limit the expansion of capitalism by policies favorable to cooperatives.

Fauquet became a figure considered to be one of the founders of the cooperative movement by the International Cooperative Alliance itself (Watkins [1986]) ${ }^{24}$. His theses were largely confirmed in the post-war period: the law of 1947 marked the unity of the cooperative enterprise, beyond specific statuses, but it took until 1968 for different cooperative movements to unite and form the Groupement National de la Coopération, the French National Association of Cooperative Federations. The consumer's cooperatives, the farmers' cooperatives and the new credit cooperatives developed both in the defense of small groups of farmers, consumers and savings (household) productions. On the other hand, the number of workers cooperatives has evolved only slightly (600 from 1910 to 1970) whereas their size grew (the largest cooperative in Europe, the AOIP (Association des ouvriers en instruments de précision [the association of precision tool workers]), has had up to 4000 employees, in mechanic telephony, outsourced to the Ministry of Communication-the PTT) (Demoustier [2001 a]).

Thus we can see that parallel to the integration of cooperatives, mutual societies and associations, in economic, industrial and social policies, the term social economy will progressively designate a field of analysis specific to economics (the welfare economics) even as economic analysis of these organizations will develop its own tools in both in continuation

\footnotetext{
${ }^{24}$ This refers for Jean François Draperi to the passage of the doctrine of the cooperative movement of "the cooperative republic" (inspired by Gide) to the "cooperative sector" (a sector not aiming to be hegemonic but to cohabit on the long term with other economic sectors) (Draperi [2000]).
} 
of (Gide) and in rupture (Fauquet) with the dominant economic analysis for a longtime to come $^{25}$.

\section{Resurgences and transformations of social economy}

From the 1970s on, the socio-economic conditions change and transform the context in which the cooperative movement developed. The international competition is growing; technological progress necessitates the mobilization of important capital. After a phase of criticism of the bureaucracy and the hierarchy by the ideas of self-management economy and then autonomy (Rosanvallon [1976]), the critics of state sponsored economic intervention became increasingly virulent, clearing the path for the liberalization of prices, of the job market, and of capital. These changes, the rising constraints pressing down on the organizations of highly competitive fields (hobbies, consumption, banking, agriculture, and also personal services, culture...), as well as the emergence of new organizations and activities notably in the accompaniment of rising numbers of people faced with the processes of social exclusion....are inscribed into a general context that lead to the regrouping of the major traditional actors of social economy, in addition to the diversification of approaches trying to understand the nature and the role of these organizations.

\section{Non-profit organizations, social economy, third sector}

In 1970, national representatives of cooperation (GNC) having a sense of the imminent changes $^{26}$, rejoined the directors of mutual societies (FNMF-Fédération nationale de la mutualité) and the associations in social work and education (UNIOPSS-Union nationale interfédérale des oeuvres privées sanitaires sociales and CCOMCEN-Comité de coordination des oeuvres mutualistes et coopératives de l'Education Nationale) for the creation of the CNLAMCA (Comité National de Liaison des Activités Mutualistes, Coopératives et Associatives $)^{27}$. During a conference in 1977, they called on Henri Desroche to discuss the denomination of their organizations that they then regrouped under the term "non-profit

\footnotetext{
${ }^{25}$ As Claude Vienney notes [1980], during this period, cooperatives are nonetheless the object of some explanatory attempts in a neo-classic approach (Emelianoff), in the framework of Marxism on the socialist market model (Lange) or in a marginal approach by some heterodox traditions around developmental issues (Perroux).

${ }^{26}$ Claude Vienney [1985] interprets it as a premonition of the de-structuration of activities and of the disengagement of the state, leaving the actors with the responsibility of their own activities that do not create enough profit and that are not a priority for the public power which would rather invest in new and upcoming sectors.

${ }^{27}$ It became the CEGES (Conseil des entreprises et des groupements de l'économie sociale Council for Enterprises and Groupings of Social Economy) in 2001.
} 
organizations". In his report, Henri Desroche insists on the problems posed by a negative definition (non profit, non lucrative, non market) and proposed to take up the term of "enterprises of Social Economy" (used in 1900 at the World Fair in Paris) to designate "an associative, participative and united economy" (Desroche [1983] and [1991]):

- Enterprises rather than organisms (then understood as organizations and movements) in order not to deny the management side, but "enterprises that are also associations, associations that are also enterprises", "mainly user's associations";

- Social Economy [de l'économie sociale] to integrate the market activity of cooperatives, and the distinction between market and capitalist and to designate a binary firm-association "in tension";

- that can incorporate "institutional" social economy (in the cooperative, mutualist and associative statuses) but also "Establishing" [Instituant] or "Emerging" social economy. Its extension can also be made towards union components (parity economy) and communal (local development).

The "changes" and "transitory phases" that affect social economy, do not take place without struggle: "Either social economy comports itself as Establishing force faced with dispositions and devices that are proposed — or opposed to it — by the Established force. Or this very social economy situates itself as an already Established organization in relation to potentials, aspirations, creativities that would posit alternatives" (Desroche [1983], p. 230). Henri Desroche thus redefines the cooperative practice as a "voluntary practice of self managed socializations" ([1981], p. 3) close to self-help, mutual aid and self-reliance.*

This reflection led these actors to publish a charter of social economy ${ }^{28}$ in 1980 . The preamble of the document affirms the economic, social and political ambitions of the cooperative, mutualist and associative movements "that proved that it is possible to reconcile efficiency and low cost, profitability and democratic action, economic truth, imagination and volontarist militancy". It defines these ambitions as voluntary, democratic enterprises "made up of devoted members, equals in duties and rights", in a particular scheme of appropriation, distribution and division of profits, promoting the training and information of members, as well as "the harmonious development of society in a perspective of individual and collective

\footnotetext{
*In English in the text [Translator's note].
} 
development". Within the scope of the social transformation that runs across this period, notably around the idea of labor managed economy, as opposed to social hierarchy (at work, at school...), it globally affirms its humanistic project: "social economy is at the service of humanity".

At the same time, at the Research Center "Travail et Sociétê" (Université Paris Dauphine), Jacques Delors ${ }^{29}$ defined the third sector which "would be able to cover economic activities (production of goods and services sold on the market) in conditions close to the current state of artisans and cooperatives, as well as social activities, in the broadest sense of the term (non-market services). That is to say: education, culture, health, welfare, mutual aid and the reform of living conditions". Breaking from hierarchy and economic concentration, that go against innovation and initiative, this new "sector" does not distinguish itself clearly by its juridical profile, nor by the nature of goods and services, nor even by its philosophical ends but rather, "it marks its innovativeness by the small size of its unities, its implantation in a decentralized universe and objectives that, although well defined, are not its own: responding to the unsatisfied, and at time unexpressed, needs; to fill the available gaps in the production of goods and services; inventing new forms of work, emphasizing the improvement of working standards, and universal participation in decision making” (Delors [1979]). By fusing different problems of economic reform (new needs for services, new needs for jobs, aspirations to transform working conditions), the idea of a third sector comes up in the larger framework of global social aspiration. It inspires a certain number of national and European public programs set up by high ranking civil servants involved in social reform ${ }^{30}$.

\section{Social economy and alternative economy}

At the heart of the socialist party, from the 1977 congress onwards, it seems that it was more the ideas Michel Rocard, rather than those of Jacques Delors, that prevailed at the beginning of the $1980 \mathrm{~s}^{31}$. Also, the creation of the DIES in 1981 constitutes a consecration of "institutionalized" social economy. This is defined by the founding decree of the DIES (December 15, 1981) as rejoining "the cooperatives, mutual societies, and (...) the associations whose activities of production assimilate them to these bodies".

\footnotetext{
${ }^{28}$ Cf. www.ceges.org.

${ }^{29}$ Cf. (Delors [1979]) et (Delors, Gaudin [1979]).

${ }^{30}$ A range of examples can be found in France from community job initiatives to the "Nouveaux services, Nouveaux emplois"; on the European level we can find local initiatives for job development and territorial and regional employment pacts.
} 
But the understanding of this notion will evolve with political conceptions and economic constraints. Thus, from 1981 to 1983, social economy enters into a mixed economy whose objective is industrial modernization; it was based on the creation or the revival of enterprises by cooperation of production, as well as the setting forth of "major" cooperatives, with recently nationalized businesses, to revive the small businesses with public investment in major industrial sectors (Rocard [1981]). From 1984, in the context of the policy de rigueur ("competitive disinflation"), the emphasis was put on decentralization and competition. The DIES is thus put under the aegis of a minister's office [Secrétariat d'Etat] for social economy and "local development" 32 . A series of measures were taken to open social economy to competition (the 1984 banking law on the universal bank; the 1985 reform of the code for a mutual insurance system...) and to draw attention to local associations. At the same time, the French influence in Brussels (thanks to Jacques Delors) led to the creation of a group for Social economy, at the heart of the European Commission, in 1989.

On the theoretical level, the juridical-economic formalization was carried out by Claude Vienney (inspired by Georges Fauquet) for the cooperatives at first and then extended to all of social economy ([1985] and [1994]). For this author, the unity of the field comes from "a correspondence between the rules of certain institutions, the place of their activities in the economy, and the identity of actors that are their participating members" (Veinney [1994], p.71). Taking an institutionalist approach ${ }^{33}$ Claude Vienney points out how social economy is a particular type of organization for "all economy as an ensemble of activities of production of goods and services functions according to social rules. The term "social" economy would be nothing but a pleonasm if all activities actually functioned according to the same rules" (Vienney [1994], p. 72). It is through a combination of juridical, economic, and sociological criteria that we can limit the domain of the organization of social economy: "the location of their activities in the economy corresponds fairly directly with their legal identifications $;{ }^{34}$ for the statutes define why people form associations (...) Their social composition is equally in correspondence with these legal statutes and these economic activities (...) In each case, it is

\footnotetext{
${ }^{31}$ An outlook of this contradictory debate can be found in a special issue of the journal Autrement [1979].

${ }^{32}$ This action was criticized by the Secrétaire d'Etat in (Gatel [1997]).

${ }^{33}$ Following George Fauquet, but also close to the Regulation School in other aspects, and more particularly to Christine André and Robert Delorme [1983].

${ }^{34}$ The clauses included in the legal statutes correspond to rules that we can gather into four main principles: reciprocal identification of associates and of the activity of the firm; equality of the associates with no relation to
} 
the ratio of participants that become members that indicates, with reference to interests, which group manages the company" (Vienney [1994], p. 10). ${ }^{35}$.

The cooperative model, notably the double quality rule which is the basis for such analysis, can be questioned for the association whose "legal status does not suffice to identify this third element of social economy. The 1901 law is ambivalent. It does not contain rules that permit us to identify reciprocally either the actors that form an association, the activities that they undertake nor to draw out the typical modes of functioning" (Veinney [1999], p.42). However, due to the existence of a process of institutionalized compromise [The Regulation School's Compromis institutionnalisé] (André, Delorme [1983]) ${ }^{36}$, "there are clauses analogue to the double relation of association and activity, introduced due to this fact, that characterize the cooperatives and the mutual societies, identifying the activities and the benefiting actors concerned" (Vienney [1994], p. 48). Thus the cooperative model is transposed to the whole of social economy ${ }^{37}$, which is shot through by a movement of transformation and materialization:

- On the level of the field itself, on the one hand, for we also see the appearance and the development of new organizations: "their vocation remains to take in charge essential yet neglected activities, but in new forms, in relation to the former institutions seeking to achieve the union of the economic and the social, that lies at their origin. These organizations, that in turn test out rules giving priority to the usefulness of activities over the profitability of capital invested therein, concerning new risks of social exclusion" (Vienney [1994], p. 117);

- On the other hand, at the heart of these organizations in the relations between the members and their companies. Thus the analysis of transformations of major cooperatives leads Vienney to identify three phases:

\footnotetext{
their participation to the activity; if allowed, the share of surplus between associates in proportion of the participation to the activity; lasting collective property of reinvested benefits.

${ }^{35}$ In Claude Vienney's case, contrary to what Laville suggests (Laville [2001]), viz. "social economy thus understood is a sign of an approach that takes up empirical realities in terms of rational action and utilitarianism of the actors", we are faced with a structuralism and not a rational choice theory (with which nonetheless it shares a quite determinist dimension).

36 "If associations can develop activities combining marketable and non-marketable resources, it is because they ask social powers to recognize the usefulness and legitimacy of the interests of their beneficiaries. In the same way, administrations that provide these resources are led to have their agreement dependant on certain statutes" (Vienney [1994], p. 48).

37 "It is insofar as they tend to get closer to the previous ones that some law 1901 associations belong to the same type of organization"(Vienney [1996], p.163).
} 
-the first is founded on the social identity of members that rally the means to meet needs; the grouping of people thus dominates the activity;

-the second where the reciprocal adjustment of activity by needs regulates the double relation between the association and the company; -the third where instability of these relations under environmental pressure leads to reversal: the company dominates the association and modifies the identity of the members.

By analyzing the relation between their own rules and those of the socio-economic systemof which they are a part-we can understand the formation and the transformation of cooperative organizations, "so that those organizations that put into effect the same principles today, can be the result of profound changes when we compare them to their historical origins" (Vienney [1980], Tome I, p. 383). Thus following this analysis, "the organizations are not immutable; they transform themselves at the same time as their environment. Certain organizations leave the domain; others are more likely to enter into it. This is not betrayal but rather an adjustment in relation to the environment" (Demoustier [2002], p. 105).

In general, the organizations of social economy (more than the former institutions) play a role in crisis regulation (as the "post-Keynesian solution" (Vienney [1985])), in sliding double quality (targeting the interest of solitary members) towards social utility (targeting collective interest).

Besides this formalized social economy, there is the tentative establishment (with lesser success in France than in Germany) a movement bearing social change, of an "alternative" economy (ALDEA-the Agence de liaison pour le développement de l'économie alternative) transformed into "Alternative and solidarity-based economy" (REAS) during the 1980s. These currents are successively fed by the journals Autogestions and then Autrement. ${ }^{38}$ Coming from a critique of institutions (referring mainly to the work of Illich [1973] and [1977]), of the hierarchy in and outside work, and of diverse experimentations, the goal of the alternative is diverse: to produce in a different way -(reflection on product utility, from

\footnotetext{
${ }^{38}$ The journal Autogestions thus praises Yugoslav, Israeli and Algerian workers managing experiences - a favorite theme of the CFDT and the PSU (in the journal Critique Socialiste), whereas the journal Autrement
} 
automobiles to weapons; on technologies-soft versus hard-, on the organization of work, partly taking up the reflection of Jacques Delors: small sized units, warmth of human relations..., and worker-management; alternative treatment (alternative medicine); educate differently (parallel school, homeschooling...) (Outrequin, Potier, Sauvage [1986]).

The founder of the REAS, Aline Archimbaud characterizes this alternative economy as "a radical form of social economy": "alternative economy is social economy for the period of concomitant crises of productivism and salaried society," due to the unacceptable effects of the mode of accumulation on the environment and society. But this alternative economy is stuck between survival strategies (by necessity) and the refusal of dominant norms (by choice); "alternative economy is the formal ideological manifestation of entrepreneurial practices or activities that are informal at first through which, by choice or by necessity, sensitive social groups try to adapt themselves or to resist the new social order" (...) "Fed by resistances and ruptures that take place in all developed societies since the mid-60s, the alternative economy movement (...) defines itself as a critical movement in society, harboring a new culture of social change" (Archimbaud [1995].) While the social priority goes from social change (with the slogan "Stop growth!") to the quest for productive growth of jobs, the movement does not find durable modes for structuring itself, except in alternative finance, now "solidarity-based" finance (savings clubs-CIGALES_, capital risk societies-La Nef, Autonomy-Solidarity_-, as well as mutual funds, now regrouped under Finansol).

The debate between worker-management and innovating forms on the one hand, and economic democracy in institutional forms of social economy on the other hand, meets a greater reflection lying at the heart of economic thought. This branch of research tries to put actually existing cooperation into perspective in the context of an analysis of the working of macroeconomic systems (notably in Israel or in Yugoslavia (Vanek [1977]) or in the relation of a confrontation between standard and heterodox currents around the respective advantages of the profit-making enterprise and the self managed firm (Tinel [2002]).

\section{Community based services, social enterprises, community-based economy, and third system}

From the beginning of the 1990s, volontarist actions and policies tried to struggle against unemployment, by supporting the development of new services likely to respond both to the 
demand for job and to the demand for services (Demoustier [2001 b]). Four practices must be pointed out, marking the expansion of the domain of the relevant activities:

- The promotion of community based services - called services solidaires - to create both jobs and necessary services, in the framework of European studies promoting certain areas of activity: youth centers, economic insertion, domestic help, environment, neighborhood restaurants, musical cafés... (Laville [1992] for example). This promotion was supported by the creation of specialized agencies such as the Agence de Développement des Services de Proximité close to the CRIDA (Centre de recherche et d'information sur la démocratie et l'autonomie) and the AIRES-SP supported by Social Centers and the HLM council housing projects. This collective, enriched at the end of the $90 \mathrm{~s}$, by the inclusion of fair trade practices (to rebuild reciprocal links between consumers in industrialized countries and producers in developing countries) tried to structure itself nationally in the network of the solidaritybased economy [Inter-Réseaux de l'Economie Solidaire] (which received fleeting recognition from the Minister of the solidarity-based economy).

- Social enterprises. Comparing the companies subsidized by the Cooperative Credit Foundation for their capacities of initiative and innovation, between the years 1992 and 2001, and the years 1983-1991, Jean-François Draperi underscored a new model for action at the heart of an economy of the social, charitable rather than egalitarian, less alternative than integrated into civil society, as a reaction to the power of a "predominant" economy productive of exclusion and inequality and of the values that it extols. Their model of reference is less the cooperative and more a working project, the social enterprise, "the actual meeting of two practical traditions: social action and social economy" (Draperi [2003], p. 49). For this "social enterprise, the choice of the associative status is thus seen as less financially and democratically demanding (no authorized capital; room to maneuver on an operational level). The study of these enterprises is the object of a European program, at the heart of the network of EMES researchers (Emergency of Social Enterprises in Europe), theorized in (Borzaga, Defourny, Adam [2001]) ${ }^{39}$.

by Alain Touraine and the journal Esprit (Demoustier [2001], pp. 107-108).

${ }^{39}$ The functioning of these organizations is described on a scale of nine criteria: four are relative to economic issues: continuing the activity of production, a high level of autonomy, a significant level of economic risk, and a 
- The poles of solidarity-based economy: under the influence of the REAS, certain local elected officials encourage strategies of territorial "alliance" to support the project members (not only in non-market services or under the associative statutes) and to "foster solidarity" between local economic actors. They are regrouped in the Réseau des Territoires for social economy, and certain amongst them have signed territorial conventions with the minister for the solidarity-based economy (whose functions were taken up by the DIES), in order to promote this conception of solidarity-based economy.

- In Europe, following the abolishment of the Social Economy unit, a program on the third system has been launched by the DGV (Direction générale Emploi et Solidarité) to promote jobs and local development (following the recommendations of the 1997 Luxemburg summit). The term "Third System" refers to "the social and economic group represented by local initiatives of job creation whose goal is not to respond, by the provision of goods and services, to needs for which neither the market nor the public sector actually seem capable of providing a adequate solution (European Commission [1999], p.8).

The first theory to differentiate these processes-between the approach in terms of the organization of solidarity-based economy and the one in terms of the dynamic of territorial solidarity - comes from the work of the CRIDA under the direction of J.L. Laville [1994]. Sociologists and political scientists refer to Karl Polanyi's approach which identifies four economic patterns (free market, redistribution, reciprocity and domestic administration) (Polanyi [1983]), to demand the reinsertion of the economic into the social, to struggle against problems brought about by the current crisis. New forms of companies should thus be promoted; they are characterized by "reciprocal tendencies, economic hybridization and democratization brought on by users and the institutional change." They generally use the associative form despite the danger of the absence of formal operational rules (Laville [1994], p. 168). Supporting community based services, thus allows new forms of regulation to be put into place on the local level and permits the establishment of "community groups, intermediaries between the anonymous collectivity and the family, (...) places likely to foster real and free solidarity, to which many people aspire" (Laville [1992], p.208). Faced with the

minimum level of paid jobs; five are relative to the social dimension: initiative coming from a group of citizens, decision power not based on the owning of capital shares, participation, limitation of the distribution of benefits, explicit goal of serving the community. 
crisis of abstract solidarity, the emergence of new concrete solidarity thus prevents the return to "inherited" solidarity (in reference to the socialist theorist Pierre Leroux).

Do these new theorized practices target the renewal of a social economy, in the process of becoming obsolete due to the utilitarianism of its members? (Laville [19994] or its extension beyond the employer and the seller represented by the cooperative (Draperi [1998], Laville [2001]). ${ }^{40}$ In the debates on the relation between social economy and solidarity-based economy, the idea of the "redundancy" of social economy and the reprise of its $19^{\text {th }}$ century political project by the solidarity-based economy (Laville [1994]) is heavily discussed. The RECMA, which taking off from the REC (Revue des études cooperatives) grew to include mutual societies cooperatives and associations. In 1986 it then became the Revue Internationale de l'économie sociale, and has carried staged these discussions, as the articles of J.M. Collombo and M. Parodi show [1997]. For these authors, "the model of social economy necessarily meets the model of solidarity-based economy through its common values of solidarity, cooperation, democratic or participative management, through its rules of "a-capitalism" (activities with non-lucrative ends, the accumulation of collective capital, etc.)" (Collombo, Parodi [1997], p. 60). Similarly after a period of opposition (service to third parties/members, solidarity/ collective egoism, the economy of the poor/ the economy of the middle-class...), the regional consultations of social economy and solidarity-based economy, started by the DIES, largely allow the establishment of points of convergence between the different dynamics (which notably allowed certain upcoming actors to access CRES centers (Chambres regionales d'économie sociale), even if in certain regions, distinct structures continue to confront each other) around the recognition of "économie solidaire et sociale." (social and solidarity-based economy) The theoretical construction of this alliance remains largely to be done (Espagne [2002]).

Another current, which is strong on the European level, is now trying to valorize and adopt the Anglo-American approach to the non-profit sector (Archambault [1996]), called third sector in certain European countries like Italy), which considers that all associations have an economic activity, on the one hand (statistically aggregating all associations in activity). On

\footnotetext{
${ }^{40}$ This approach thus asserts the priority of social relations over activity and overestimates emergence (initiative, innovation) while neglecting consolidation (as the perpetuation of activity can necessitate an alienation from social community links, so as to develop productivity and investment). Informal participation and local solidarity are privileged in internal democracy, which can weaken collective and economic life. In the end, the use of such
} 
the other hand, it assimilates all the non-profit making to non-commerciality, according to Anglo-American fiscal principles (largely taken up ever since by the French Fiscal teaching). Inspiring projects of the constitution of "a satellite account" of social economy in national accounting, this approach leads to exclude (or artificially adjoin) the larger part of French cooperatives and mutual benefit societies. On the other hand, this sector includes the foundations (many trans-Atlantic ones) whose paradoxical particularity is to pursue social goals with entirely financial means (revenues on invested capital). This approach is debatable, according to Michel Garrabé who points out the uncertainty of repartition based either on the on the mode of functioning (rules for surplus distribution), or on the object (tuition, housing development...) (Garrabé, Bastide, Fas [2001], pp. 30-31).

Many theorists thus rely on Neo-Classical analysis — or its offshoots in broad standard theory (in terms of (Favereau [1989]) to explain the growing role of these organizations in a mixedmarket economy. For Burton Weisbrod [1998] for instance, the non profit sector is seen as a group of organizations taking in charge the "public goods" with a limited audience. These activities are not taken into account by the market due to their externalities and their "intergenerational" output, nor by the state that, in sticking to the analysis of public choices, is only interested by the preoccupations of the average voter. For Henry Hansmann [1996], the constraint of non distribution of profit reduces the incentive of an organization to profit from the asymmetry of information in favor of its managers and at the loss of consumers. Nonprofit organizations inspire consumer confidence, even when quality is not observable. It thus carries a comparative advantage vis-à-vis profit-making organizations when it comes to establishing a relationship of trust, a necessary condition for the transaction to go through. In both a continuation of and in breaking from these notions, the theory of trust (Richez-Battesti [2000]) along with Albert Hirschman's theory [1970] offers an explanation of the services offered by certain types of coops and non-profit organizations: for certain types of services (such as education, health and recreation for which all product characteristics likely to satisfy the "consumers" are not known until after the consumption of the "product." The "voice" given by the status of being an enterprise of social economy, in guaranteeing the exchange of information between the producer and the consumer, contributes to the obtaining of a more satisfying service than assured by "defection" (Ferraton, Frobert [2001], p. 200).

structures as mere instruments can happen quickly in so far as social and economic needs are strong and the autonomy of the collective project is weak. 
To be sure, these theories can partially explain both the rise of such organizations and the existence of consumerist behavior therein ${ }^{41}$. However, they do not account for the collective operation (approached by the economics of convention), nor their modes of transformation (explained on a macroeconomic level by Regulation School, for example concerning community based services (Du Terte [1999]). We can point out here the contribution of collective agreement theory across the approach to "the Economics of Worth" [les économies de la grandeur] (Boltanski, Thévenot, 1991). In fact, this theory was often used to analyze the operation of organizations of social economy, that are the kinds of enterprises characterized by a wider potential logic for action (other than industrial and market conventions, there also exist domestic and civic conventions etc.), a peculiarity brought to the fore in the case of cooperative bankers, thus setting them apart from commercial banks (Boltanski, Pailler [2000]), or more generally, for different associations (Enjolras [1993]). There are various relations between the economics of worth and social economy qua social practice: it is an analytic framework commonly used in an optic of audits and internal action - as in the case of the transformation of Crédit Mutuel de Bretagne, faced with a growth and identity crisis- to show the heterogeneity of the comportment of different funds joined at the heart of the same organization, in the attempt to attain new organizational compromises (Pailler [1992]); or for the construction and the management of new forms of multi-partner cooperatives referred to as the SCIC (sociétés coopératives d'intérêt collectif) (Margado [2002]). It is also cited explicitly as a source of inspiration for the constitution of a "bilan sociétal", a tool provided by the CJDES (Centre de jeunes dirigeants et acteurs de l'économie sociale) destined to evaluate the "impact" and the contribution of these social economic organizations to their environment (whether consecutive to their internal operation or their criteria for development and management) (Capron, Leseul [1997]). This instrument is currently being promoted in the larger general context of the social responsibility of firms.

We can thus conclude of the necessity for these various theoretical sources to understand the not only the emergence of these organizations, but also the social behavior of actors that participate in them, as well as their modes of transformation in a society undergoing profound changes (Demoustier, [2000]). ${ }^{42}$

\footnotetext{
${ }^{41}$ That said, these theories can't help us understand why in reality these different specific activities are characterized by a multiplicity of forms of organizations (and not only one which would be the most efficient) or characterized by strong and lasting differences between countries.

${ }^{42}$ Even if the framework of this appropriation/synthesis still remains to be defined.
} 


\section{Conclusion: On lessons learnt from a historical approach and the potential to renew research in social economy}

The historical approach teaches us four main lessons:

- Theoretical arguments tend to be recurrent. Let's go over the theories mentioned: the liberal economic approach (immaterial production in the $19^{\text {th }}$ century; charity and nonmarket production in the $20^{\text {th }}$ century); the reformist approach (solidarity and/or economic democracy); the transformative approach (alternative or "radical"). It is the complex relation of social economy to the "standard theory" (Favereau [1989]) of economics, that presents all the characteristics of "normal science" (Kuhn [1970]) which is put into question each time. Certain approaches tend to share, while others oppose the main elements of the dominant paradigm of the economic science of the period. Moreover there can be great rifts between the theory (on nature, role and place) and the doctrine (cooperation at the beginning of the century, the values declared today). This also holds true in the relation of theory to practice: the Industrial association of Saint Simon and his followers cleared the path for both workers association and technocratic industrialism; Walras' working class association embodied itself through the cooperation of production, consumption and credit and through popular shareholding; the cooperation enterprise of Fauquet eclipsed the rise in the economy of working class associations; social economy and solidarity-based economy nowadays can mask collective egoism...

- According to the period, social economy as practice is mainly recognized either by its objectives (health and education, the right to work, social progress in the $19^{\text {th }}$ century, innovation and modernization, local development in the 1970s and the 1980s, social relations, the creation of jobs and activities in the 1990s...); or by its sources that actually refer to institutional frameworks (patronage, association, social rights) followed by statutory frameworks (cooperatives, mutual societies and associations); or else by their modus operandi, that is to say their internal characteristics (groupings of people and indivisible resources, Association-enterprise and double quality, reciprocity and hybridization of resources, non repartition of surplus...);

- The statutes are bound to evolve, as a function of the insertion of the cooperative into its environment. Already in the 1860s, a debate stirred the cooperators on the question of a specific status (to reconcile the recognition of economic activity and democratic aspirations: given the difficulties of the use of limited partnership, the status of 
anonymous company was preferred to its own status prepared by Léon Walras. ${ }^{43}$ Nowadays, the mutualist status is being reexamined through different reforms (19852000); the associative status is being brought up to date with new rules framing its economic activity; the cooperative status expanded through the access of external investors (the 1992 law), by the openness to new professions (ex. doctors...), and by new forms of membership (such as collective interest cooperative companies). As Claude Vienney ${ }^{44}$ has pointed out, it seems that the statutes, although not magic potions are not neutral solutions either. ${ }^{45}$ They are afflicted by a certain inertia that slows down the adoption of new statutes or the transformation of older ones.

- A dynamic vision is necessary to understand the transformation and perception of the field. Recently, solidarity-based economy puts the emphasis on social mobilization of new social actors, insists on the rise of activities rather than on their structural mode or their consolidation. Nonetheless, the priority given to fitting the activity into local social connections, to reinforce interpersonal relations and give rise to solidarity (against social anomie) develops the roles of internal reciprocity and redistribution, rather than the qualification of individual actors and the involvement of the organization, sources of job development, as well as the expansion of activities and structures.

These observations can thus offer proposals to renew research programs in social economy. The ambivalent and diverse character of social economy-questioning elsewhere the ambiguous position of the researcher (Demoustier, Duriez [1997])—examines more generally research in social science for it points out that the comprehension of economic, political and social phenomena calls for a dialogue between theory and practice, between inductive and deductive methods.

\footnotetext{
${ }^{43} \mathrm{~A} 19^{\text {th }}$ century author expresses his opinion about this transformation in the following terms: "the first ones, in 1848 , were all in the name of the collectivity. Everyone was claiming to be responsible for the acts of society and to be the guarantor of its debts. In 1863, we prefer simple shares. The manager(s) are responsible for all they own as the law does not allow otherwise. The other associates are only share holders, that is to say that their responsibility does not exceed the amount of their shares. After the 1867 law that makes the formation of anonymous societies easy, all societies (...) want to take this form for it allows even the managers to limit their responsibility to a small subscription (...) that is to say, to take in advance all precautions so that if the firm goes bankrupt each and everyone can get out without worry. It's a misrepresentation of the honor of the firm and not a show of courage" (Huber-Valleroux [1884], p. 234). The discourse about the functioning of actual firms as a perversion or disloyalty towards the original principles of cooperation is already in place!

44 "It is thus not enough that propriety be collective and that the 'democratic management' be written in the statutes for all the members to have real power or even to be part of its expression" (Vienney [1966], p. 353).

${ }^{45}$ It refers to the conception of institutions and rules as being constraining, but also open to interpretation to some extent, according to institutionalist approaches like the Regulation School or the economy of conventions.
} 
- We are in a transitional phase, a "crisis" according to the Regulation School (Boyer, Saillard [2002]): new actors are appearing; new activities are structuring themselves according to the rules of social economy; older forms are being examined in their transformational logic. Being concerned with the study of both the emerging and consolidated forms of social economy, we need to take into account elements of change and continuation at the same time;

- Social economy is not an economic system on its own (as both Gide and Vienney point out), the statutes are questioned by the affirmation of durable informal groups (de facto associations), by the tensions with artisanal logic (individual appropriation of quasi-familial collective forms), the public logic (semi-public associations) and financial logic (the external development of activity, transfer to a subsidiary, development of individual capital...) (Demoustier, Rousselière, Clerc, Cassier [2003]). In adopting an institutionalist approach that takes into account the statuses without closing us in a static vision, we must also account for diversity;

- Social economy is undergoing a renaissance and a transformation, but it is also consolidating itself, contrary to theses that confine it to a strictly palliative or transitory role. It thus seems appropriate to examine the very objects, peculiarities, the place and the role of the socio-economic relations that structure our society. In other terms, we must finally deal with unity. 


\section{Bibliography}

ANDRE C., Delorme R. [1983], L'Etat et l'Economie, Paris, Le Seuil.

ARCHAMBAUlt E. [1996], Le secteur sans but lucratif, Paris, Economica.

ARCHIMBAUD A. [1995], «L'économie alternative, forme radicale de l'économie sociale », RECMA - Revue internationale de l'économie sociale, vol. 73, $\mathrm{n}^{\circ} 256$, avril, pp. 67-71.

AUTREMENT [1979], Et si chacun créait son emploi ? Le retour des entrepreneurs : ils inventent collectivement une économie différente, $\mathrm{n}^{\circ} 20$, septembre.

BANCAL J. [1987], «Proudhon et son héritage » in ORY P. (dir.), Nouvelle histoire des idées politiques, Paris, Hachette, Collection Pluriel, pp. 264-280.

Bastiat F. [1864], Oeuvres complètes, Tome sixième, Harmonies économiques, Paris, Guillaumin. (disponible sur http://gallica.bnf.fr).

BATIFOULIER P. [1995], L'économie sociale, Paris, PUF, Que-sais-je ?.

BLANC L. [1847], L'organisation du travail, $5^{e ̀ m e}$ édition revue, corrigée et augmentée, Paris, Société de l'industrie fraternelle. (disponible sur http://gallica.bnf.fr).

Boltanski L., TheVenot L. [1991], De la justification : les économies de la grandeur, Paris, PUF, (On Justification: The Economics of Worth, Princeton University Press, forthcoming)

Boltanski L., Pailler P. [2000], «Logiques d'action et cohésion d'une entreprise coopérative » in Coopératives et mutuelles: des entreprises efficaces et différentes sur le marché, Actes des rencontres de l'Office Central du 26-27 octobre, pp. 22-34.

BorZaga C., DEFOURnY J., ADAM S. [2001], The emergence of the social enterprise, London, Routledge.

Boyer R., SAILlard Y. (dir.) [2002], Regulation Theory : The State of the Art, London, Routledge.

Buchez P. [1831], «Moyen d'améliorer la condition des salariés des villes », repris in DeSROCHE H. [1981], Sociétaires et compagnons, Paris, Editions ouvrières, pp. 31-36.

Buchez P. [1866], Traité de politique et de science sociale, Paris, Amyot. (disponible sur http://gallica.bnf.fr).

CAPRON M., LeSEUl G. [1997], «Pour un bilan sociétal des entreprises », RECMA - Revue internationale de l'économie sociale, vol. 75, n²66, octobre, pp. 28-41.

CASIMIR-PERIER A. [1864], Les sociétés de coopération, La consommation, le crédit, la production, l'amélioration morale et intellectuelle par l'association, Paris, Dentu 
Libraire-éditeur. (disponible sur http://gallica.bnf.fr).

Collombo J.-M., PARodi M. [1997], «L'économie solidaire a-t-elle besoin de l'économie sociale ? », RECMA - Revue internationale de l'économie sociale, vol. 75, n²64.

COMMISSION EUROPEENNE [1999], Troisième système et emploi, Rapport du séminaire conjoint, Bruxelles, Direction générale «Emploi, relations industrielles et affaires sociales ».

Delors J. [1979], «Le troisième secteur : le travail au-delà de l'emploi », Autrement, 20 septembre.

Delors, J., Gaudin, J. [1979], «Pour un troisième secteur coexistant avec celui de l'économie de marché et celui des administrations », Problèmes économique, $\mathrm{n}^{\circ} 1616,28$ mars.

Demoustier D. [1988], «Léon Walras, théoricien de la libre concurrence et défenseur des associations populaires et de l'intervention étatique », Problèmes économiques, $\mathrm{n}^{\circ} 2051$, 10 février, pp. 19-26.

Demoustier D. [2000], «Economie sociale et théorie économique », Les Cahiers pour l'histoire de l'épargne, n², juin, pp. 37-49.

Demoustier D. [2001 a], L'économie sociale et solidaire, s'associer pour entreprendre autrement, Paris, Syros, Alternatives économiques.

DEMOustieR D. [2001 b], «France: Voluntary Sector Initiatives for Work Integration » in SPEAR, ROGER; ET AL. (eds), Tackling social exclusion in Europe: The contribution of the social economy, Aldershot, U.K.; Burlington, Vt. and Sydney: Ashgate, 2001, pp. 111-44.

DemoustiER D. [2002], «Une lecture française : l'analyse proposée par Claude Vienney estelle encore pertinente aujourd'hui ? » in CHOMEL A. (dir.), Coopération et économie sociale au "second" XXè siècle, Claude Vienney (1929-2001), Paris, L'Harmattan, pp. 103-107.

DemoustieR D. [2003], «Les associationnistes français, le marché et l'Etat», Communication au colloque Histoire des représentations du marché, Association Charles Gide pour l'étude de la pensée économique, 25-27 septembre.

Demoustier D., Duriez B. [1997], «Chercheurs et associations, le respect de la différence, au risque du conflit » in ChOPART J.-N., OUtin J.-L., PALIER B., RAUlt D., VidANA J.-L. (dir.), Produire les solidarités, la part des associations, Paris, MIRE-Ministère de l'emploi et de la solidarité, Fondation de France, pp. 392-398.

Demoustier D., Rousseliere D. [2003], «L'apport des entreprises d'économie sociale au débat sur la recomposition du travail et de l'activité » in Mondialisation et régulation 
sociale, Paris, L'Harmattan, pp. 591-606.

Demoustier D., Rousseliere D., Clerc J.-M., CASsier B. [2003], « L'entreprise collective : unité et diversité de l'économie sociale », RECMA - Revue internationale de l'économie sociale, vol. $82, \mathrm{n}^{\circ} 290$.

DeSROCHE H. [1981], Sociétaires et compagnons, Paris, Editions ouvrières.

Desroche H. [1983], Pour un traité d'économie sociale, Paris, CIEM.

DesRoche H. [1991], Histoires d'économies sociales, Paris, Syros.

DeSRoche H. [1993], «Léon Walras et/ou Charles Gide: Quelle économie sociale?», RECMA - Revue internationale de l'économie sociale, vol. 72, n²50, pp. 115-126.

Dockes P. [1996], La société n'est pas un pique-nique : Léon Walras et l'économie sociale, Paris, Economica.

DRAPERI J.-F. [1998], «L'économie sociale, un ensemble d'entreprises aux formes infiniment variées », RECMA - Revue internationale de l'économie sociale, vol. 77, n²68, pp. 1023.

DRAPERI J.-F. [2003], «L'entreprise sociale en France, entre économie sociale et action sociale », RECMA - Revue internationale de l'économie sociale, vol. 82, n²88, avril, pp. 48-66.

Dunoyer C. [1830], Nouveau traité d'économie sociale, Paris, Sautelet et Cie, Libraireséditeurs. (disponible sur http://gallica.bnf.fr).

ENJOLRAS B. [1993], «Vers une théorie socio-économique de l'association : l'apport de la théorie des conventions », RECMA - Revue internationale de l'économie sociale, vol. 71, n²50, pp. 93-107.

ESPAGNE F. [2002], «Sur l'économie sociale et solidaire », RECMA - Revue internationale de l'économie sociale, vol. 81, n²86, novembre, pp. 13-22.

FAUQUET G. [1935], Le secteur coopératif, Paris, Institut des études coopératives, 1965.

FAUQUET G [1948], «Les Institutions coopératives dans l'économie et dans la législation », Revue internationale du travail, vol. 58, $\mathrm{n}^{\circ} 4$, octobre, pp. 521-534.

FAVEREAU O. [1989], « Marchés internes, marchés externes », Revue Economique, vol. 40, $\mathrm{n}^{\circ} 2$, mars, pp. 273-328.

Ferraton C., Frobert L. [2001], «L'économie comme solidarité chez Albert O. Hirschman », Economie Appliquée, vol. 54, n², juin, pp. 193-213.

FINANCE I. [1879], «Des associations » in Séances du congrès socialiste ouvrier de France, Troisième session tenue à Marseille, Marseille, Imprimerie Générale Doucet, pp. 323-329. (disponible sur http://gallica.bnf.fr). 
Garrabe M., Bastide L., FAS C. [2001], «Identité de l'économie sociale et de l'économie solidaire », RECMA - Revue internationale de l'économie sociale, vol. 80, $\mathrm{n}^{\circ} 280$.

GATEL J. [1997], «SCOP et développement local : le rendez-vous manqué », Economie et Humanisme, $\mathrm{n}^{\circ} 341$, juin, pp. 58-61.

GIDE C. [1890], Quatre écoles d'économie sociale, Paris, Archives de sciences sociales de la coopération et du développement, octobre-décembre 1987.

GIDE C. [1905], L'économie sociale, les institutions du progrès social, Paris, L'Harmattan (préface de Danièle Demoustier), à paraître 2004.

GIDE C. [1910], La coopération, Paris, Sirey.

GIDE C. [1924], Le programme coopératiste, Cours au collège de France, Paris, Edition FNCC (disponible sur http://gallica.bnf.fr).

GiDE C., [1926], Cours d'économie politique, Neuvième édition, Paris, Sirey (2 tomes).

GuESLIN A. [1996], «Usager-consommateur et économie sociale au XIXè siècle» in Horellou-Lafarge C. (dir.), Consommateur, usager, Citoyen: Quel modèle de socialisation ?, Paris, L'Harmattan, Logiques Sociales, pp. 139-154.

GuesLin A. [1998], L'invention de l'économie sociale, Paris, Economica.

Hansmann H. [1996], The ownership of enterprise, Cambridge, The Belknap Press of Harvard University.

Hirschman A. O. [1970], Défection et prise de parole, Paris, Fayard, L'espace du politique, 1995.

Hubert-VALleroux P. [1884], Les associations coopératives en France et à l'étranger, Paris, Guillaumin et Cie. (disponible sur http://gallica.bnf.fr).

ILLICH I. [1973], La convivialité, Paris, Le Seuil.

ILLICH I. [1977], Le chômage créateur, postface à la convivialité, Paris, Le Seuil.

JAURES J. [1903], «Critique de l'économie sociale », La petite république socialiste, 24 février in «Un siècle d'économie sociale », RECMA - Revue internationale de l'économie sociale, vol. 79, $\mathrm{n}^{\circ} 275-276,2000$, p. 37.

KuHN T. S. [1970], La structure des révolutions scientifiques, Paris, Flammarion, Champs, 1983.

LAVILLE J.-L. (dir.) [1992], Les services de proximité en Europe, Paris, Syros.

LAVILLE J.-L. (dir.) [1994], L'économie solidaire, une perspective internationale, Paris, Desclée de Brouwer.

LAVILLE J.-L. [2001], «Vers une économie sociale et solidaire ?», RECMA - Revue internationale de l'économie sociale, vol. 80, n 281. 
LOWITT T. [1962], «Marx et le mouvement coopératif », Cahiers de l’ISEA, Série S, nº, pp. 79-85.

MARGAdo A. [2002], «SCIC, société coopérative d'intérêt collectif », RECMA - Revue internationale de l'économie sociale, vol. 81, $\mathrm{n}^{\circ} 284$.

MARX K. [1959], Le Capital, Livre Troisième, Tome II, Paris, Editions Sociales.

MarX K. [1963], Euvres, Tome I, Paris, Gallimard, La Pléiade.

MiLl J.-S. [1848], Principes d'économie politique, avec quelques unes de leurs applications à l'économie sociale, Paris, Guillaumin et Cie, 1873.

MiLl J.-S. [1889], L'utilitarisme, Paris, Félix Alcan éditeur (disponible sur http://gallica.bnf.fr).

NeURISSE A. [1983], L'économie sociale, Paris, PUF, Que-sais-je ?.

Отт A. [1851], Traité d'économie sociale ou l'économie politique au point de vue du progrès, Paris, Renou éditeur. (disponible sur http://gallica.bnf.fr ).

Outrequin P., Potier A., Sauvage P. [1986], Les entreprises alternatives, Paris, Syros, Alternatives économiques.

PAILLER P. [1992], «L'entreprise et ses valeurs, l'expérience des logiques d'action au Crédit Mutuel de Bretagne », RECMA - Revue internationale de l'économie sociale, vol. 70, $\mathrm{n}^{\circ} 245,3$ ème trimestre, pp. 49-61.

PENIN M. [1990], «L'économie sociale à travers les rapports de Charles Gide sur l'exposition universelle de $1900 »$, Revue de l'économie sociale, n¹9, pp. 137-157.

POLANYI K. [1983], La grande transformation, Paris, Gallimard.

ProcacCi G. [1993], Gouverner la misère, la question sociale en France, 1789-1848, Paris, Le Seuil.

Proudhon P.-J. [1840], Qu'est ce que la propriété ?, Ou Recherche sur le principe du droit et du gouvernement, Paris, Garnier-Flammarion, 1966.

Proudhon P.-J. [1846], Système des contradictions économiques ou philosophie de la misère, Paris, Editions de la Fédération Anarchiste, 1983 (3 tomes).

Proudhon P.-J. [1953], «Mutuellisme et fédéralisme» in Textes choisis, présentés et commentés par Joseph Lajugie, Paris, Dalloz, pp. 372-483.

REMOND R. [1987], «Postface » in ORY P. (dir.), Nouvelle histoire des idées politiques, Paris, Hachette, Collection Pluriel, pp. 763-770.

RicheZ-BATTESTI N. [2000], «Quelles attentes pour la clientèle des banques coopératives ? Une approche en terme de confiance », Les Cahiers pour l'histoire de l'épargne, $\mathrm{n}^{\circ} 2$, juin, pp. 87-94. 
ROCARD M. [1981], «Entretien », La vie, 21 octobre, repris in JEANTET T., VERDIER R., L'économie sociale, Paris, CIEM, 1982, p. 539.

Rosanvallon P. [1976], L'âge de l'autogestion, Paris, Le Seuil.

Stoskopf N. [2002], «La fondation du Comptoir national d'escompte de Paris, banque révolutionnaire (1848) », Histoire, Economie et Société, vol. 21, n³, pp. 395-411.

TEXIER J. [2002], «La question de l'appropriation sociale : La définition du communisme comme libre association des travailleurs et le point de vue de Marx sur les coopératives ouvrières », La Pensée, n³31, pp. 69-93.

Tinel B. [2002], «Hiérarchie et pouvoir en microéconomie », Economie et sociétés, Série Oeconomia, vol. 36, n¹1-12, novembre-décembre, pp. 1789-1821.

VANEK J. [1977], The labor managed economy, New York, Cornell University Press.

VIENNEY C. [1960], Vers une analyse économique du secteur coopératif, Paris, Bureau d'Etudes coopératives et communautaires.

VIENNEY C. [1966], L'économie du secteur coopératif français, Paris, Cujas.

VIENNEY C. [1980], Socio-économie des organisations coopératives, Paris, CIEM.

VIENNEY C. [1985], «Les acteurs, les activités et les règles des organisations de l'économie sociale en France », Document DESUP Economie Sociale, Université Paris I, octobre.

VIENNEY C. [1994], L'économie sociale, Paris, La Découverte, Repères.

VIENNEY C. [1996], «L'usager consommateur dans les théories économiques et les organisations de l'économie sociale au XIXè siècle » in Horellou-LafARGE C. (dir.), Consommateur, usager, Citoyen : Quel modèle de socialisation ?, Paris, L'Harmattan, Logiques Sociales, pp. 155-167.

VIENNEY C. [2000], «Qu'est ce que l'économie sociale ?», RECMA - Revue internationale de l'économie sociale, vol. 79, n²75-276, pp. 38-41.

WALRAS L. [1865], Les associations populaires de consommation, de production et de crédit, Paris, Dentu Libraire éditeur. (disponible sur http://gallica.bnf.fr).

WALras L. [1896], «Études d'économie sociale» in WAlras A., Walras L., Euvres complètes, Tome IX, Paris, Economica, 1990.

WALRAS L. [1898], «Études d'économie politique appliquée » in WALRAS A., WALRAS L., Euvres complètes, Tome X, Paris, Economica, 1992.

Watkins W. P. [1986], Co-operative Principles, Today and Tomorrow, Manchester, Holyoake Books, International Cooperative Alliance.

WEISBROD B. [1988], The non profit economy, Cambridge, Harvard University Press. 


\section{Social Economy as Social Science and Practice: \\ Historical Perspectives on France}

Session : Social Economics and Economic Sociology ..................................................... 1

Introduction: The definition of Social economy, a recurrent question ................................. 2

Social economy and classical political economy ........................................................................5 5

Social economy as an enhancement of political economy ................................................... 5

Critique of political economy and the right to work by association ..................................... 7

From the emancipation through cooperation and mutual benefit to reform through social

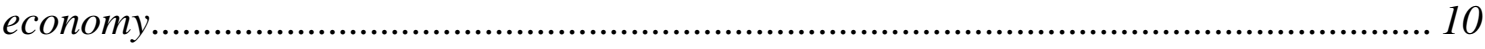

Social Economy and the constitution of Economics .............................................................. 14

Social economy between morality and science: The Walras/Gide debate ........................... 14

From social economy to cooperative economy: On Georges Fauquet's contribution .......... 17

Resurgences and transformations of social economy .............................................................. 20

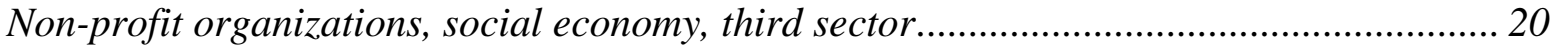

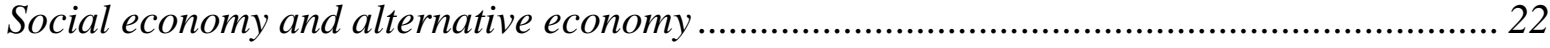

Community based services, social enterprises, community-based economy, and third system

Conclusion: On lessons learnt from a historical approach and the potential to renew

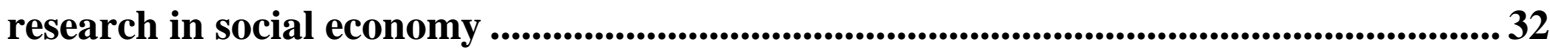

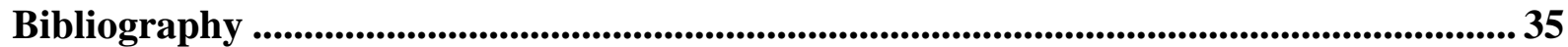

